Biografistyka Pedagogiczna

Rok 2 (2017) nr 1

ISSN 2543-6112; e-ISSN 2543-7399

DOI: $10.36578 /$ BP.2017.02.10

Katarzyna Sabat*

\title{
W strukturach (anty)komunistycznych - informatorzy Oddziału „Tarzana”
}

\section{In the Structures (Anti)Communist - Informants of the Branch „Tarzan”}

\begin{abstract}
Since 1944 the security apparatus has been the basic tool of repression in the communist Poland. Subject to the persecution were mainly soldiers belonging to the structures of the independence underground. In the northern part of the fork of the Vistula and the San rivers Forest Branch of Tadeusz Gajda 'Tarzan` served a unique role in the Rzeszow District of the National Military Union in the fight with the process of strengthening the communists' power. The activities of the Branch 'Tarzan' and its soldiers were the merit of not only of the commanding skills, but also owning the net of the informants, who worked in the structures of the Office of Public Security and Citizen's Militia, decided to help the independence underground. Biographies of people presented in the article, found on the border of the two opposing ideas, endangering in the adopted service the most important value that is life.
\end{abstract}

Keywords: Polish independence underground, communist structure, biographies, the security apparatus, Citizen's Militia, cooperation

* Katarzyna Sabat - mgr, doktorantka w Instytucie Pedagogiki Katolickiego Uniwersytetu Lubelskiego Jana Pawła II, sabat128@vp.pl. 
Losy Polski i Polaków w XX w. naznaczone były wyjątkowym tragizmem wywołanym dynamiką wydarzeń związaną z wojnami, procesami zmian ustrojowych i następującą w ich wyniku adaptacją nowego porządku, który burzył dotychczasową hierarchię wartości i wyznawane ideały. Czas ten był okresem trudnych wyborów i decyzji. To rozdroże, gdzie często wybieraną ścieżkę stanowiła wąska krawędź biegnąca na pograniczu życia i śmierci. Zakończenie działań militarnych i niemieckiej okupacji miało przynieść polskiej ludności poprawę jakości życia pod względem ekonomicznym, socjalnym, gospodarczym oraz prawnym. Czas, który nastał w Polsce po 1944 r., przez zwolenników nowej władzy, podporządkowanej polityce ZSRR, propagandowo nazywany był okresem „szczęśliwych obywateli". Wśród społeczeństwa polskiego panowały także odmienne poglądy, cześć obywateli była zdania, iż w okresie Polski Ludowej „gwałt uchodził za męstwo, a cnota i patriotyzm były reliktem przeszłości"1. Tylko najodważniejsi decydowali się na działalność skierowaną przeciwko narzuconym strukturom aparatu komunistycznego, doznając przy tym represji ze strony totalitarnych władz.

Rosnąca potęga nowej władzy komunistycznej w Polsce wynikała nie tylko z odniesionych sukcesów militarnych, ale także z niezaspokojenia ambicji przywódców. Dokonywany przewrót społeczny przez kierownictwo komunistyczne wykorzystywał aspiracje robotników i chłopów pochodzących ze wsi, umożliwiając im w szybki sposób awans społeczny oraz zapewniając bezpieczeństwo materialne i władzę. Korzyści te były obustronne, gdyż żądano w zamian posłuszeństwa i ślepej wiary w nowy porządek polityczny².

W systemie władzy komunistycznej jedną z najistotniejszych ról odgrywał aparat bezpieczeństwa, który służył jako podstawowe narzędzie represji oraz był zaangażowany w proces umacniania władzy ludowej ${ }^{3}$. Monitorowa-

1 Napis umieszczony na tablicy pamiątkowej w miejscowości Boćki, znajdującej się w powiecie bielskim w województwie podlaskim. Pierwsza część pomnika powstała w 1959 r. „ku czci poległych funkcjonariuszy MO w walce z bandami o utrwalenie władzy ludowej w latach 1944-1949". W 1990 r. społeczeństwo ufundowało nową tablicę o treści: „Pomnik ten pochodzi z okresu, w którym gwałt uchodził za męstwo, a cnota i patriotyzm były reliktem przeszłości. Walczącym o demokrację społeczeństwo gminy Boćki 3 V 1990".

2 W. Roszkowski, Historia Polski 1914-2004, Warszawa 2004, s. 177.

3 D. Iwaneczko, Ogniwo strachu. Urząd Bezpieczeństwa w Lubaczowie 1944-1956, Rzeszów 2012, s. 7 . 
nie wszelkich sfer funkcjonowania państwa i społeczeństwa przypisywano terenowym organom bezpieczeństwa, nazywanym urzędami bezpieczeństwa publicznego (UBP). Działania te miały szczególny wymiar aktywności zwróconej w kierunku polskiej wsi i jej mieszkańców. Obserwacji oraz kontroli poddano zarówno instytucje gminne, jaki i organizacje polityczne, gospodarcze, społeczne, a także szkoły4. Pod koniec 1944 r. Urząd Bezpieczeństwa (UB) posiadał około 2,5 tys. funkcjonariuszy, a w 1945 r. było ich bez mała 24 tys. Na jednego funkcjonariusza UB przypadało około 1300 obywateli ${ }^{5}$. Każda akcja polityczna powodowała rozbudowę agentury, którą tworzono m.in. w zakładach pracy, szkołach, partiach politycznych, a nawet wśród duchowieństwa ${ }^{6}$.

Tworzenie aparatu bezpieczeństwa w województwie rzeszowskim ${ }^{7}$ zapoczątkował rozkaz personalny wydany przez kierownika Resortu Bezpieczeństwa Publicznego (RBP), Stanisława Radkiewicza z 1944 roku$^{8}$. Na terenie Rzeszowszczyzny Wojewódzki Urząd Bezpieczeństwa Publicznego (WUBP) powstał w Rzeszowie ${ }^{9}$. W jego skład wchodziło kilkadziesiąt wydziałów, m.in. Kontrwywiad, Wydział do Walki z Bandytyzmem, Wydział Więzień i Obozów, Wydział Śledczy ${ }^{10}$. Na wyżej wspomnianym obszarze w tym samym okresie powstały również Powiatowe Urzędy Bezpieczeństwa Publicznego (PUBP), m.in. w Nisku oraz Tarnobrzegu ${ }^{11}$.

4 Tamże, s. 86-87.

5 K. Szwagrzyk, Aparat bezpieczeństwa w latach 1944-1956, w: Aparat bezpieczeństwa w Polsce. Kadra Kierownicza 1944-1956, red. K. Szwagrzyk, t. 1, Warszawa 2005, s. 20.

6 J. Borowiec, Aparat bezpieczeństwa a wojskowy wymiar sprawiedliwości. Rzeszowszczyzna 1944-1954, Warszawa 2004, s. 91.

7 Województwo rzeszowskie zostało utworzone 18 sierpnia $1945 \mathrm{r}$. Powstało z połączenia czterech powiatów województwa krakowskiego oraz tych obszarów województwa lwowskiego, które pozostały w granicach Polski. W granicach województwa rzeszowskiego znalazł się także powiat tarnobrzeski, który w okresie powojennym składał się z 9 gmin (Baranów, Charzewice, Chmielów, Dęba, Grębów, Radomyśl n. Sanem, Tarnobrzeg, Trześń, Zbydniów) na terenie którym znajdowało się łącznie 72 gromady. Dz. U., 1945, nr 27, poz. 168.

8 D. Iwaneczko, Ogniwo strachu. Urząd Bezpieczeństwa w Lubaczowie 1944-1956, s. 34.

9 D. Iwaneczko, Z. Nawrocki, Województwo rzeszowskie, w: Aparat bezpieczeństwa w Polsce. Kadra Kierownicza 1944-1956, red. K. Szwagrzyk, t. 1, Warszawa 2005, s. 381.

10 Tamże, s. 382-388.

11 Tamże, s. 400-403. 
Inne miejsce w aparacie władzy komunistycznej pełniły jednostki Milicji Obywatelskiej (MO), których funkcjonowanie w kraju rozpoczęło się w drugiej połowie 1944 r., a od 1949 r. ich działalność została scalona z pracą aparatu bezpieczeństwa ${ }^{12}$. Na terenie powiatu tarnobrzeskiego zorganizowano 12 posterunków milicji ${ }^{13}$, w których pod koniec 1944 r. zatrudnionych zostało 204 funkcjonariuszy MO, w tym kilku pracowników cywilnych ${ }^{14}$. Osoby ten należały najczęściej do Armii Krajowej (AK), Batalionów Chłopskich (BCh) bądź były przedwojennymi policjantami. Wobec milicjantów podejrzanych o kontakty ze strukturami państwa podziemnego stosowano wydalenie ze służby pod pretekstem redukcji etatów, ponieważ stanowili oni „elementy reakcyjne i niepewne"15. Do głównych zadań funkcjonariuszy Mo można było zaliczyć zwalczanie przestępczości kryminalnej i gospodarczej, ochronę ładu, bezpieczeństwa oraz porządku publicznego, wykonywanie zleceń władzy sądowniczej, administracyjnej i prokuratury ${ }^{16}$. Zasadniczym zadaniem milicji w latach 1944-1948 była ochrona programu przeobrażeń rewolucyjnych oraz sytuacji wewnętrznej kraju przed atakami podziemia antykomunistycznego ${ }^{17}$.

Pod koniec 1944 r. represjom aparatu bezpieczeństwa byli poddawani głównie żołnierze należący do AK oraz innych organizacji działających w podziemiu antykomunistycznym ${ }^{18}$. Przekonanie o konieczności walki z ustrojem komunistycznym było oczywiste dla większości społeczeństwa, które nie chciało przyjąć narzuconych koncepcji ówczesnej władzy i systemu jej sprawowania. Jednym z głównych powodów, który przyczynił się do podtrzymywania ruchu

12 D. Byszuk, Komenda Powiatowa Milicji Obywatelskiej $w$ Tarnobrzegu $w$ latach 1944-1954, w: Powiat tarnobrzeski w latach 1944-1956, red. Z. Nawrocki, T. Zych, Tarnobrzeg 2005, s. 85.

13 Posterunki milicji na terenie powiatu tarnobrzeskiego zorganizowano w miejscowościach, w których znajdowały się przed drugą wojną światową, czyli w: Antoniowie, Baranowie, Chmielowie, Dębie, Jastkowicach, Grębowie, Radomyślu, Rozwadowie, Stalach, Tarnobrzegu, Trześni i Zbydniowie; tamże, s. 88.

14 Tamże, s. 88.

15 Tamże, s. 95.

16 P. Majer, Milicja Obywatelska w systemie organów władzy PRL (zarys problematyki i źródła), Toruń 2003, s. 319-420.

17 Z. Jakubowski, Milicja Obywatelska 1944-1948, Warszawa 1988, s. 7.

$18 \mathrm{~J}$. Borowiec, Aparat bezpieczeństwa a wojskowy wymiar sprawiedliwości. Rzeszowszczyzna 1944-1954, s. 106-107. 
oporu, były masowe prześladowania ich członków przez komunistyczny aparat bezpieczeństwa ${ }^{19}$. Istniejące, choć wyniszczone drugą wojną światową, formacje polskiego państwa podziemnego nie pogodzily się ze zniewoleniem kraju i postanowiły walczyć w obronie Ojczyzny.

Jedną ze struktur polskiego podziemia niepodległościowego było Narodowe Zjednoczenie Wojskowe (NZW), politycznie podporządkowane Stronnictwu Narodowemu (SN), które tworzyły oddziały Narodowej Organizacji Wojskowej (NOW), wyodrębnione wcześniej ze struktur $\mathrm{AK}^{20}$. Na obszarze dzisiejszego województwa podkarpackiego istniały najsilniejsze struktury NZw, w skład których wchodził Okręg Rzeszowski. Zasięgiem obejmował prawie wszystkie powiaty byłego województwa rzeszowskiego (bez Gorlic, Jasła i Sanoka) oraz powiaty innych województw (Janów Lubelski, Tarnów, Sandomierz, Opatów, Ostrowiec Świętokrzyski, Staszów ${ }^{21}$. Od maja 1945 r. do sierpnia 1948 r. komendantami Okręgu byli: Kazimierz Mirecki „Kazimierz”, Józef Sałabun „Grom”, Kazimierz Nizieński „Waluś” oraz Piotr Woźniak „Wir”22.

W marcu 1945 r. z rozkazu komendanta Oddziałów Leśnych Okręgu Rzeszowskiego - Franciszka Przysiężniaka ${ }^{23}$ - został utworzony oddział partyzancki,

19 W. J. Muszyński, Antykomunistyczne powstanie, w: Do końca wierni. Żołnierze wyklęci 1944-1963, red. D. P. Kucharski, R. Sierchuła, Poznań 2014, s. 22.

20 S. Poleszak, R. Wnuk, Zarys dziejów polskiego podziemia niepodległościowego 19441956, http://pamiec.pl/pa/edukacja/akcje-i-obchody/ogolnopolskie/1-marca-narodowy dzien/historia/10063,dok.html?poz=2, dostęp: 07.04.2016.

21 S. Socha, Czerwona śmierć czyli narodziny PRL, Stalowa Wola 2000, s. 99.

22 K. Kaczmarski, M. Krzysztofiński, Podziemie antykomunistyczne na Rzeszowszczyźnie po 1944 r., „Nowe Państwo - Niezależna Gazeta Polska”, dodatek specjalny IPN, 8 (2010) S. 5.

23 Franciszek Przysiężniak „Ojciec Jan”, „Marek” (1909-1975) - od 1943 r. dowódca samodzielnego oddziału partyzanckiego NOW-A9oK, w $1945 \mathrm{r}$. został Komendantem Oddziałów Leśnych Okręgu Rzeszowskiego Nzw. Dowodził zgrupowaniem oddziałów NZW w walce z NKWD pod Kuryłówką w maju 1945 r. Poszukiwany przez funkcjonariuszy UB przeniósł się na Pomorze, gdzie pracował pod przybranym nazwiskiem. Aresztowany 15 maja 1946 r., a na mocy amnestii zwolniony w 1947 r. Ponownie aresztowany we wrześniu 1948 r., gdzie w więzieniu we Wronkach przebywał do $1954 \mathrm{r}$. Pośmiertnie awansowany do stopnia pułkownika Sił Zbrojnych Rzeczpospolitej Polskiej, odznaczony Orderem Virtuti Militari i Krzyżem Armii Krajowej; Sz. Nowak, Oddziały Wyklętych, Warszawa 2014, s. 78-83, 95-96, L. Żebrowski, Żołnierze wyklęci. Antykomunistyczne podziemie zbrojne po 1944 roku, Warszawa 1999, s. 153. 
który przybrał nazwę Oddział Leśny „Tarzana”24. Jego dowódcą mianowano Tadeusza Gajdę „Tarzana”25. Oddział stał się kolejną formacją antykomunistyczną Okręgu Rzeszowskiego Narodowego Zjednoczenia Wojskowego obok słynnych i znanych zgrupowań partyzanckich Józefa Zadzierskiego „Wołyniaka”, Bronisława Gliniaka „Radwana”, Stanisława Pelczara „Majki”, Franciszka Szarka „Lisa”, Józefa Krawczyka „Kudłatego” czy Stanisława Orłowskiego vel Woźnickiego "Weuwarta” ${ }^{26}$. W początkowym okresie formowania oddział liczył zaledwie 12 członków, natomiast $50 \mathrm{w}$ lipcu $1945 \mathrm{roku}^{27}$. Wstępowały do niego osoby zdekonspirowane, dezerterzy Ludowego Wojska Polskiego ${ }^{28}$, a także żołnierze służący w innych placówkach rzeszowskich struktur NZW ${ }^{29}$. Teren działania oddziału „Tarzana” i podległych mu żołnierzy stanowił obręb północnej części powiatu tarnobrzeskiego, a także powiat niżański (miejscowości Pysznica i Jastkowice-Lipowiec) w byłym województwie rzeszowskim ${ }^{30}$.

24 S. Socha, Czerwona śmierć czyli narodziny PRL, s. 194-196.

25 Tadeusz Gajda (1924-1946) - ur. w Charzewicach (obecnie dzielnica Stalowej Woli), od 1941 r. należał do struktur Narodowej Organizacji Wojskowej przyjmując pseudonim „Tarzan”, w 1943 r. został skierowany do oddziału Now-AK „Ojca Jana”, w którym ukończył „leśną” Szkołę Podchorążych, otrzymując stopień plutonowego podchorążego. W 1944 r. brał udział w bitwie partyzanckiej na Porytowym Wzgórzu, w październiku 1944 r. został powołany do służby 25 Pułku 19 Dywizji Piechoty Armii Berlinga, skąd zdezerterował. W 1945 r. został dowódcą Oddziału Leśnego Okręgu Rzeszowskiego NZW, a w marcu 1946 r. szefem Pogotowia Akcji Specjalnej przy Inspektoracie „Tatar”. 7 sierpnia 1946 r. Gajda został aresztowany przez funkcjonariuszy UB w Tarnowie, a 14 października 1946 r. w więzieniu przy ul. Montelupich w Krakowie wykonano karę śmierci; Archiwum Instytutu Pamięci Narodowej, Oddział w Rzeszowie [dalej: AIPN Rz], 043/12, Meldunek Specjalny, 10 października 1946, k. 32; AIPN Rz, 0172/4/J, Charakterystyka nr 6-c bandy Narodowej Organizacji Wojskowej pod dowództwem Gajdy Tadeusza ps. „Tarzan”. Charakterystyka dowódcy bandy, 24 czerwca 1985, k. 1-2; S. Socha, Czerwona śmierć czyli narodziny PRL.

26 T. Bereza, P. Chmielowiec, K. Kaczmarski, Polskie podziemie niepodległościowe $w$ województwie rzeszowskim 1944-1956, w: Atlas polskiego podziemia niepodległościowego1944-1956, red. R. Wnuk, S. Poleszak, A. Jaczyńska, M. Śladecka, WarszawaLublin 2007, s. 178-179.

27 AIPN Rz, 043/12, Banda „Tarzana”, k. 2.

28 AIPN Rz, O172/4/J, Charakterystyka nr 6-c bandy Narodowej Organizacji Wojskowej pod dowództwem Gajdy Tadeusza ps. „Tarzan”. Liczebność bandy, 24 czerwca 1985, k. 2.

29 B. Szwedo, „Tarzan” i jego żołnierze, „Tarnobrzeskie Zeszyty Historyczne”, 13 (1996) s. 13.

30 AIPN Rz, O172/4/J, Charakterystyka nr 6-c bandy Narodowej Organizacji Wojskowej pod dowództwem Gajdy Tadeusza ps. „Tarzan”. Teren działania, 24 czerwca 1985, k. 6. 
$\mathrm{Na}$ wspomnianym obszarze Gajda zorganizował placówki terenowe ${ }^{31}$ wraz z obsadą dowódczą.

Cechą charakterystyczną organizacji Nzw była szczególna dbałość o zachowanie wojskowego charakteru, stylu działania i wzorowej dyscypliny. Obowiązkiem każdego partyzanta było noszenie munduru wraz z naszywką na lewym ramieniu, na której widniała czaszka z napisem „Śmierć wrogom Ojczyzny”. Oprócz tego na wojskowej czapce widniał Orzeł Biały z koroną, a na piersiach ryngraf z wizerunkiem Matki Bożej. W szczególności wojskową specyfiką odznaczały się oddziały partyzanckie NZw na obszarze Mazowsza, dowodzone przez Zbigniewa Kuleszę „Młota”, Józefa Kozłowskiego „Lasa” czy patrole Pogotowia Akcji Specjalnej pod przywództwem Mieczysława Dziemieszkiewicza „Roja”, Witolda Boruckiego „Dęba”, Stanisława Suchotniaka „Szarego”32. Nieliczna dokumentacja fotograficzna oraz publikacje o charakterze regionalnym nie pozwalają jednoznacznie stwierdzić wojskowego charakteru ${ }^{33}$ oddziału „Tarzana”. Omawiana formacja wyróżniała się wzorową dyscypliną wśród partyzantów, czego powodem był niezłomny charakter dowódcy.

Do bieżących zadań członków podziemia antykomunistycznego należało odbijanie z aresztów i więzień osób osadzonych przez funkcjonariuszy UBP i Mo. Prowadzono działania propagandowe, wywiadowcze oraz likwidacyjne, wymierzone w prześladowców i niebezpiecznych konfidentów. W celu zaopatrzenia w żywność i zdobycia funduszy na dalszą działalność niepodległościową przeprowadzano akcje ekspropriacyjne w bankach, spółdzielniach i państwowych gospodarstwach rolnych. Do innych zadań można zaliczyć ochronę ludności wiejskiej przed samowolą władzy komunistycznej, kary chłosty wymierzone gorliwym sprzymierzeńcom władzy ludowej, a w szczególności osobom

31 Dokładna ilość placówek należących do Oddziału „Tarzana” jest trudna do ustalenia. Poddając analizie dostępne źródła, szacuje się, iż było ich 11 bądź 17 usytuowanych w widłach Wisły i Sanu; AIPN Rz 043/12, Doniesienie, 26 stycznia 1946, k. 9; AIPN Rz 0172/4/J, Charakterystyka nr 6-c bandy Narodowej Organizacji Wojskowej pod dowództwem Gajdy Tadeusza ps. „Tarzan”. Obsada personalna placówki, 24 czerwca 1985, k. 3 .

32 Historia Roja, czyli w ziemi lepiej słychać, [film], reż. J. Zalewski, Dr Watkins 2016.

$33 \mathrm{Na}$ tym etapie badań nie dotarłam do pisemnych raportów z przeprowadzanych akcji, które Tadeusz Gajda „Tarzan” jako dowódca oddziału leśnego przekazywał zwierzchnikom Okręgu Rzeszowskiego NZw. Nie ulega wątpliwości, iż takie raporty uległy zniszczeniu bądź są przechowywane w prywatnych archiwach. 
należącym do Polskiej Partii Robotniczej (PPR) ${ }^{34}$. Za przykład może posłużyć zdarzenie z 6 grudnia 1945 r., kiedy to podczas odprawiania nabożeństwa w kościele parafialnym w Zaleszanach, Tadeusz Gajda „Tarzan” przyprowadził do kościoła miejscowego sekretarza PPR, nakazał klęknąć mu przed ołtarzem i złożyć przysięgę, która na podstawie zeznań księdza Jakuba Przybyłowicza ${ }^{35}$, brzmiała „że będzie dobrym Polakiem" ${ }^{\prime 36}$. Po złożeniu tej przysięgi „podali sobie ręce i pocałowali się w twarz" ${ }^{\prime \prime}$. Komisja Porozumiewawcza Stronnictw Politycznych potępiła to zajście, uznając je za profanację kościoła ${ }^{38}$.

Działalność Oddziału Leśnego „Tarzana” rozpoczęła się na przełomie marca i kwietnia 1945 r. Pierwszą akcją na terenie powiatu tarnobrzeskiego było wymierzenie kary chłosty członkom Stronnictwa Ludowego (SL) i PPR współpracującymi z NKWD i UBP ${ }^{39}$. Do innych ważniejszych działań można zaliczyć rozbrojenie posterunku $\mathrm{MO}^{40}$ i Zarządu Gminnego w Zbydniowie ${ }^{41}$, a także posterunku MO w Gorzycach ${ }^{42}$. Czynności o charakterze ekspropriacyjnym przeprowadzane w miejscowościach Rozwadów, Skowierzyn ${ }^{43}$ i Zbydniów ${ }^{44}$ w odbiorze miejscowej ludności czyniły Oddział „Tarzana” zgrupowaniem

34 W. J. Muszyński, Antykomunistyczne powstanie, s. 22-23.

35 Jakub Przybyłowicz (1893-1967) - święcenia kapłańskie przyjął w 1922 r. w Przemyślu, jako wikariusz pełnił posługę duszpasterską w Kosinie, Przeworsku, Mrowli, Brzyskach i Bukowsku, w latach 1931-1936 był proboszczem w Rumnie, a od $1941 \mathrm{r}$. zajmował stanowisko administratora, a następnie proboszcza parafii Zaleszany; Jubileusz 10o-lecia Kościoła Św. Mikołaja Biskupa w Zaleszanach 1906-2006, red. J. Domin, M. Cygan, Zaleszany 2006, s. 51-52.

36 AIPN Rz, 107/109, Protokół przyjęcia ustnego zawiadomienia o przestępstwie, k. 43. W cytatach zachowano oryginalną pisownię.

37 Tamże.

38 S. Dobosz, Dzieje polityczne Tarnobrzega i powiatu tarnobrzeskiego w latach 19441975, w: Tarnobrzeg. Dzieje miasta 1939-1999, red. F. Kiryk, Mielec 2010, s. 109.

39 S. Socha, Czerwona śmierć czyli narodziny PRL, S. 195.

40 AIPN Rz, 716/46, Wykaz doniesień o ważniejszych zbrodniach dokonanych w powiecie tarnobrzeskim w 1945 r., k. 17.

41 D. Garbacz, Tadeusz Gajda „Tarzan”, „Sztafeta”, 27 (2014) nr 9, s. 15.

42 AIPN Rz, 0172/4/J, Karta na czyn przestępczy dokonany przez bandę „Narodowa Organizacja Wojskowa” pod d-twem Gajda Tadeusza ps. „Tarzan, 14 października 1980.

43 AIPN Rz, 043/12, Notatka informacyjna, k. 5-7.

44 S. Socha, Czerwona śmierć czyli narodziny PRL, s. 204. 
bandyckim i złodziejskim ${ }^{45}$. Dzięki prężnie działającej propagandzie komunistycznej część społeczeństwa lokalnego nie rozumiała, a także nie chciała dostrzec potrzeb i motywów walki „leśnych” partyzantów. Rekwirowana żywność, ubrania oraz zdobyte pieniądze ${ }^{46}$ przeznaczane były na utrzymanie członków Oddziału i Komendy Okręgu Rzeszowskiego NZW oraz jako zapomoga dla rodzin partyzantów, których żywicieli pozbawiła władza komunistyczna.

Oddział Leśny „Tarzana” był jedynym zgrupowaniem NZW w północnej części wideł Wisły i Sanu starającym się powstrzymać proces umacniania się nowej władzy w Polsce, zapoczątkowany w 1944 r. Działalność „Tarzana” i jego żołnierzy na wyżej wspomnianym terenie trwała ponad rok. Fakt ten był zasługą dowódcy oddziału, posiadającego umiejętności dowódcze oraz siatkę informatorów, pracujących w strukturach UBP i MO na terenie byłego województwa rzeszowskiego. Osoby te znalazły się „na granicy” utrwalającej się władzy komunistycznej i walczącego z nią polskiego podziemia niepodległościowego. Informatorzy „Tarzana”, współpracując z oddziałem, narażali własne życie w podjętej służbie.

Materiały archiwalne, które wykorzystałam do opracowania biografii, nigdy wcześniej nie były poddane analizie oraz publikowane ${ }^{47}$. Uzyskane informacje pochodzą z teczek personalnych, akt nadzoru i akt procesowych udostępnionych przez Instytut Pamięci Narodowej Oddział w Rzeszowie, ze zbiorów prywatnych oraz wywiadu.

Wśród informatorów oddziału „Tarzana” wyjątkową rolę pełniła Maria Strutyńska z domu Borowiak. Urodziła się 25 maja 1925 r. w Grabczynach,

45 Oddział Leśny nr 2 „Tarzana” nosił miano bandy „Tarzana”, a członków polskiego podziemia niepodległościowego porównywano do niemieckich zbrodniarzy i morderców. Takie określenia odnajdujemy we wspomnieniach wydawanych w okresie Polskiej Rzeczpospolitej Ludowej; L. Korga, Lata Polski Ludowej, w: Z rewolucyjnych walk na Rzeszowszczyźnie, red. Z. Trawińska, Rzeszów 1979, s. 190-200.

46 Oddział „Tarzana” przeprowadzał akcje ekspropriacyjne jedynie na zwolennikach ustroju komunistycznego, członkach PPR, funkcjonariuszach MO i UBP i organizacjach będących na usługach władzy podporządkowanej ZSRR.

47 Wyjątek stanowi publikacja J. Borowca, Polityka karna wobec przestępstw i wykroczeń funkcjonariuszy Urzędu Bezpieczeństwa w województwie rzeszowskim (194419156), Rzeszów 2014, w której autor wymienia osobę Marii Strutyńskiej wśród funkcjonariuszy uB skazanych przez Wojkowy Sąd Rejonowy w Rzeszowie w 1953 r. 
położonych wówczas w powiecie tarnobrzeskim ${ }^{48}$. W okresie niemieckiej okupacji jej rodzina zamieszkała w Dwikozach na terenie powiatu sandomierskiego, utrzymując się z prowadzenia cegielni ${ }^{49}$.

W lipcu 1944 r. z chwilą nadejścia frontu i jego ustabilizowania nad Wisłą [...] została wraz ze swoją rodziną ewakuowana przez władze wojsk wyzwoleńczych z Dwikozów ${ }^{50}$, jako pasa frontowego i w związku z tym zamieszkała na stałe w grom. Grabczyny pow. Tarnobrzeg we własnym domu swojego ojca ${ }^{51}$.

W lutym 1945 r. Strutyńska podpisała deklarację przystąpienia do $\mathrm{PPR}^{52}$, motywując swoje postępowanie następująco: „Wstępując do partii miałam na celu objęcie pracy zarobkowej, która z uwagi na ciężkie warunki materialne była wówczas dla mnie konieczna"53. Maria Strutyńska pracę na stanowisku maszynistki w PUBP w Tarnobrzegu rozpoczęła 26 marca 1945 roku ${ }^{54}$. Oprócz wykonywanych obowiązków wynikających z powierzonego jej stanowiska, pełniła rolę sekretarki PUBP, uzupełniając dzienniki korespondencji i przyjmując oświadczenia funkcjonariuszy do służby w strukturach $\mathrm{UB}^{55}$, miała więc dostęp do tajnych dokumentów i informacji o charakterze państwowym.

Do nawiązania współpracy Strutyńskiej z Oddziałem Tadeusza Gajdy „Tarzana" doszło w czerwcu 1945 roku ${ }^{56}$. Pierwsze spotkanie kobiety z dowódcą oddziału przygotował Jan Oczak, który należał do organizacji niepodległościowej „Tarzana” ${ }^{57}$. Maria opisywała tę sytuację w następujący sposób:

48 AIPN Rz, 05/19, Kwestionariusz osobowy na pomocnika bandy p.n. NOW Gajdy Tadeusza, ps. „Tarzan” opisanej w charakterystyce Nr 6-C, 20 maja 1980, k. 300.

49 AIPN Rz, 122/269, Protokół przesłuchania podejrzanego, 24 stycznia 1953 r., k. 24.

50 Zachowano oryginalną pisownię.

51 AIPN Rz, 122/269, Akt oskarżenia przeciwko Strutyńskiej Marii c. Adama, osk. z art. 8 Dekretu z dnia 16 listopada 1945, 19 marca 1953, k. 46.

52 AIPN RZ, 122/269, Protokół przesłuchania podejrzanego, 24 stycznia 1953, k. 24.

53 Tamże.

54 AIPN Rz, 122/269, Wojewódzki Urząd Bezpieczeństwa Publicznego w Rzeszowie do Naczelnika Wydziału d/s. Funkcjonariuszy wUBP w Rzeszowie, 18 marca 1953, k. 42.

55 AIPN Rz, 122/269, Protokół przesłuchania podejrzanego, 24 stycznia 1953, k. 24.

56 AIPN Rz, 122/269, Protokół przesłuchania podejrzanego, 14 marca 1953, k. 38.

57 AIPN Rz, 122/269, Protokół przesłuchania świadka, 12 marca 1953, k. 34-35. 
Po południu jak zwykle w dzień wolny od pracy, do babki przyszły kobiety i prowadziły ze mną pogawędkę. Z tymi kobietami i ja siedziałam obok domu. W pewnym czasie kobiety zrobiły ruch powtarzając słowa: „Tarzan, Tarzan jedzie". Gdy się oglądnęłam zobaczyłam około 20-tu ludzi uzbrojonych i umundurowanych, jadących na koniach w naszym kierunku. Kiedy wymieniona grupa zbliżyła się do nas, wtedy jeden z mężczyzn podbiegł do mnie i powiedział: „Maryś chodź bo «Tarzan» chce się z tobą widzieć”. [...] Podeszłam więc ze Stępniem do jednego z osobników tej grupy, a wtedy Stępień powiedział: „To jest właśnie «Tarzan»”. „Tarzan” siedział wówczas na koniu, z którego nie schodząc podał mi rękę, a następnie począł coś do mnie mówić. [...] Ja wyraziłam zgodę na współpracę z nimi i ustosunkowałam się do nich pozytywnie $[\ldots]^{58}$.

Wstępując w struktury podziemia antykomunistycznego, Strutyńska przyjęła pseudonim „Maria” ${ }^{59}$ lub „Marysia”60, który w zeznaniach kobiety jest podawany zamiennie. Pracownica PUBP w Tarnobrzegu przekazywała informacje Tadeuszowi Gajdzie na stacji kolejowej w Zbydniowie ${ }^{61}$, w lokalach konspiracyjnych w Tarnobrzegu lub za pomocą „skrzynki kontaktowej”, znajdującej się pod kamieniem w pobliżu mieszkania Gajdów, a także poprzez rodziców "Tarzana” - Józefa Gajdę „Zawiszę” i Magdalenę Gajdę pełniącą funkcję łączniczki w oddziale ${ }^{62}$.

Wiadomości przekazywane przez Strutyńską były objęte ścisłą tajemnicą służbową UB. Wynosiła ona z UB dokumenty dla partyzantów, była wśród nich m.in. kopia miesięcznego sprawozdania z pracy PUBP w Tarnobrzegu wysłana do wUBP w Rzeszowie, która zawierała „wszelkie dane Urzędu, jak ilość posiadanej agentury, osiągnięcia w danym okresie sprawozdawczym w pracy, oraz zadania do kontynuowania pracy na przyszłość"63. Podczas spotkania

58 AIPN Rz, 122/269, Protokół Rozprawy Głównej w sprawie karnej p-ko Strutyńskiej Marii c. Adama osk. z art. 8 Dekretu z 16 listopada 1945, 15 kwietnia 1953, k. 68.

59 AIPN Rz, 122/269, Protokół przesłuchania podejrzanego, 10 grudnia 1952, k. 7.

60 AIPN Rz, 122/269, Protokół Rozprawy Głównej w sprawie karnej p-ko Strutyńskiej Marii c. Adama osk. z art. 8 Dekretu z 16 listopada 1945, 15 kwietnia 1953, k. 69.

61 Wywiad przeprowadzony z Henrykiem Strutyńskim przez autorkę artykułu dnia 2 maja 2016 (w zbiorach autorki).

62 AIPN Rz, 122/269, Akt oskarżenia przeciwko Strutyńskiej Marii c. Adama, osk. z art. 8 Dekretu z dnia 16 listopada 1945, 19 marca 1953, k. 46-48.

63 Tamże, k. 47. 
z łączniczką Tadeusza Gajdy, „Marysia” przekazała także „odpis ulotki wydawanej przez nielegalną organizację »Biały Orzeł« która była [jej] dana do sporządzenia z niej odpisu, odpis listy członków Partii względnie pracowników PUBP w Tarnobrzegu oraz odpisy różnych innych dokumentów Urzędu Bezpieczeństwa" ${ }^{64}$. Do innych doniesień należy zaliczyć wiadomości o charakterze pracy UB, meldunki o planowanych aresztowaniach członków struktur niepodległościowych ${ }^{65}$, odpis z blankietów kwestionariusza informatora $\mathrm{UB}^{66}$ oraz kwestionariusz dla kandydatów wstępujących w struktury UB, a także doniesienia agencyjne ${ }^{67}$.

9 sierpnia 1945 r. Strutyńska na własną prośbę została zwolniona z posady maszynistki w PUBP w Tarnobrzegu ${ }^{68}$, podpisując zobowiązanie dotrzymania tajemnicy „o wszelkich sprawach służbowych, które doszły do [jej] wiadomości w czasie pełnienia służby"69. W czasie podpisywania tego zobowiązania, władze UBP nie wiedziały o współpracy maszynistki z organizacją niepodległościową struktur NZW. Informacje te pozyskano dopiero w lipcu 1952 r., podczas przesłuchań kierownika PUBP w Tarnobrzegu - Ludwika Moskwy. W trakcie zeznań nadmienił on, iż „wówczas sekretarką Urzędu w Tarnobrzegu była młoda panienka, blondynka, okrągła na twarzy, której było na imię Janina i prawdopodobnie zamieszkiwała w Skowierzynie pow. Tarnobrzeg"70. Wiadomości przedstawione przez Moskwę nie były dokładne, ale stały się podstawą do podjęcia czynności dochodzeniowo-śledczych przez PUBP w Tarnobrzegu wobec Strutyńskiej.

10 grudnia 1952 r. Wojskowa Prokuratura Rejonowa w Rzeszowie postanowiła o tymczasowym aresztowaniu Marii Strutyńskiej na okres dwóch miesięcy. Areszt przedłużany był przez prokuratora dwukrotnie ${ }^{71}$. Podczas osa-

64 AIPN RZ, 122/269, Protokół przesłuchania podejrzanego, 10 grudnia 1952, k. 10-11.

65 AIPN Rz, 122/269, Akt oskarżenia przeciwko Strutyńskiej Marii c. Adama, osk. z art. 8

Dekretu z dnia 16 listopada 1945, 19 marca 1953, k. 47-48.

66 AIPN RZ, 122/269, Protokół przesłuchania podejrzanego, 10 grudnia 1952, k. 10.

67 AIPN RZ, 122/269, Raport, 19 grudnia 1952, k. 20.

68 AIPN Rz, 122/269, Wojewódzki Urząd Bezpieczeństwa Publicznego w Rzeszowie do Naczelnika Wydziału d/s. Funkcjonariuszy wUBP w Rzeszowie, 18 marca 1953, k. 42. 69 AIPN RZ, 180/124/J, Zobowiązanie, 8 sierpnia 1945, k. 4.

70 AIPN Rz, 052/355, Protokół przesłuchania podejrzanego, 9 lipca 1952, k. 6.

71 AIPN Rz, 122/269, Postanowienie o tymczasowym aresztowaniu, 10 grudnia 1952, k. 12. 
dzenia kobiety w areszcie sporządzono cztery obszerne protokoły przesłuchań „Marysi"72, a także protokoły przesłuchań świadków, którymi byli: Kazimierz Gajda $^{73}$, Magdalena Gajda ${ }^{74}$, Ludwik Moskwa ${ }^{75}$ i Jan Oczak ${ }^{76}$. W akcie oskarżenia zarzucono Marii Strutyńskiej, że

[...] w okresie od maja do 9 sierpnia 1945 r. na terenie Tarnobrzegu, jako maszynistka Powiatowego Urzędu Bezpieczeństwa Publicznego, działając na szkodę Państwa Polskiego, przekazywała dla d-cy bandy rabunkowo-terrorystycznej NSZ Gajdy Tadeusza ps. „Tarzan” wiadomości stanowiące tajemnicę organów $\mathrm{BP}^{77}$.

15 kwietnia 1953 r. w Wojskowym Sądzie Rejonowym w Rzeszowie przeprowadzono rozprawę główną przeciwko Marii Strutyńskiej ${ }^{78}$. Ze względu na charakter sprawy sąd wykluczył jawność przewodu sądowego ${ }^{79}$, jak wówczas tłumaczono dla "dobra Państwa"80. Wyrok został ogłoszony 16 kwietnia 1953 r., na mocy którego była informatorka oddziału „Tarzana” została skazana na 6 lat więzienia i utratę praw publicznych oraz obywatelskich praw honorowych na okres dwóch lat ${ }^{81}$. Odbywając karę pozbawienia wolności w więzieniu w Rzeszowie ${ }^{82}$,

72 AIPN RZ, 122/269, Protokół przesłuchania podejrzanego, 10 grudnia 1952, k. 7-11; AIPN RZ, 122/269, Protokół przesłuchania podejrzanego, 11 grudnia 1952, k. 14-18; AIPN RZ 122/269, Protokół przesłuchania podejrzanego, 24 stycznia 1953, k. 24-27, AIPN Rz, 122/269, Protokół przesłuchania podejrzanego, 14 marca 1953, k. 38-39.

73 AIPN Rz, 122/269, Protokół przesłuchania świadka, 23 stycznia 1953, k. 22-23.

74 AIPN Rz, 122/269, Protokół przesłuchania świadka, 6 lutego 1953, k. 28-29.

75 AIPN Rz, 122/269, Protokół przesłuchania świadka, 14 marca 1953, k. 36-37.

76 AIPN Rz, 122/269, Protokół przesłuchania świadka, 12 marca 1953, k. 33-35.

77 AIPN Rz, 122/269, Akt oskarżenia przeciwko Strutyńskiej Marii c. Adama, osk. z art. 8 Dekretu z dnia 16 listopada 1945, 19 marca 1953, k. 48.

78 AIPN Rz, 122/269, Protokół Rozprawy Głównej w sprawie karnej p-ko Strutyńskiej Marii c. Adama osk. z art. 8 Dekretu z 16 listopada 1945, 15 kwietnia 1953, k. 67-79.

79 AIPN Rz, 122/269, Protokół posiedzenia niejawnego, 3 kwietnia 1953, k. 55.

80 AIPN Rz, 122/269, Protokół Rozprawy Głównej w sprawie karnej p-ko Strutyńskiej Marii c. Adama osk. z art. 8 Dekretu z 16 listopada 1945, 15 kwietnia 1953, k. 67.

81 AIPN Rz, 122/269, Wyrok w imieniu Polskiej Rzeczpospolitej Ludowej, 16 kwietnia 1953, k. $90,94$.

82 AIPN RZ, 122/269, Zawiadomienie o ukończeniu postępowania karnego, 25 kwietnia 1953, k. 105. 
Strutyńska oczekiwała narodzin dziecka ${ }^{83}$. Przed rozwiązaniem przeniesiono ją do więzienia w Grudziądzu ${ }^{84}$, gdzie „przebywały kobiety, które miały rodzić, z małymi dziećmi [...], gdyż był tam szpital więzienny i żłobek"85.

Prośby męża Marii - Henryka Strutyńskiego - kierowane do Kancelarii i Prezesa Rady Ministrów Polskiej Rzeczpospolitej Ludowej ${ }^{86}$, a także do Komitetu Centralnego Polskiej Zjednoczonej Partii Robotniczej ${ }^{87}$ przyczyniły się do przedterminowego zwolnienia kobiety z odbywania kary i przywrócenia jej praw publicznych oraz obywatelskich praw honorowych ${ }^{88}$. W 1993 r. Strutyńska została odznaczona Krzyżem Kawalerskim Orderu Odrodzenia Polski ${ }^{89}$, a dwa lata później Krzyżem Narodowego Czynu Zbrojnego ${ }^{90}$. W 1995 r. Sąd Warszawskiego Okręgu Wojskowego w Warszawie na sesji wyjazdowej w Lublinie unieważnił wyrok z dnia 16 kwietnia 1953 r. skazujący Marię Strutyńską na karę 6 lat pozbawienia wolności i utratę praw publicznych ${ }^{91}$.

Oddział Leśnym „Tarzana” miał również informatorów w szeregach funkcjonariuszy Mo, którzy pełnili swą służbę na terenie powiatu tarnobrzeskiego. Wiadomości dostarczane przez milicjantów umożliwiły m.in. skuteczne rozbrojenie posterunków milicji w Gorzycach, Grębowie czy Zbydniowie przez "Tarzana” i jego żołnierzy. Dzięki współpracownikom obejmującym stanowiska w MO, oddział pozyskiwał tajne dokumenty i informacje o planowanych operacjach względem struktur podziemia niepodległościowego, a także zamierzonych represjach wśród ludności cywilnej. Akcje rozbrojeniowe, do których

83 AIPN Rz, 122/269, Do Szefa Najwyższej Prokuratury Wojskowej w Warszawie, 17 maja 1953, k. 112.

84 AIPN Rz, 122/269, Więzienie w Grudziądzu I Wojskowy Sąd Rejonowy w Rzeszowie, 18 sierpnia 1953, k. 114 .

85 Zbiory prywatne p. Haliny Bogaczyk, Związek Więźniów Politycznych Okresu Stalinowskiego Zarząd Główny w Warszawie, 17 lipca 1992, [pismo].

86 AIPN Rz, 122/269, Do Kancelarii Rady Ministrów Polskiej Rzeczpospolitej Ludowej w Warszawie, 28 czerwca 1953, k. 125.

87 AIPN Rz, 122/269, Do Komitetu Centralnego Polskiej Zjednoczonej Partii Robotniczej, 28 maja 1953, k. 135.

88 AIPN RZ, 122/269, Wojskowy Sąd Rejonowy w Rzeszowie, 21 stycznia 1954, k. 139.

89 Zbiory prywatne p. Haliny Bogaczyk, Legitymacja nr 207-93-115, Warszawa, 5 listopada 1993.

90 Zbiory prywatne p. Haliny Bogaczyk, Legitymacja nr 8-95-487, Warszawa, 11 kwietnia 1995.

91 AIPN Rz, 122/269, Postanowienie Sądu Warszawskiego Okręgu Wojskowego na sesji wyjazdowej w Lublinie, 6 marca 1995, k. 161/1. 
przyczynili się funkcjonariusze Mo, pozwoliły niejednokrotnie ocalić życie osób zdekonspirowanych oraz należących do struktur antykomunistycznych.

Funkcjonariuszem MO i jednocześnie informatorem Tadeusza Gajdy był Julian Chruściel. Stanowisko milicjanta Posterunku MO w Zbydniowie objął 14 września 1945 r. ${ }^{92}$, natomiast do oddziału „Tarzana” dołączył 15 listopada $1945 \mathrm{roku}^{93}$. Nawiązanie współpracy wyżej wspomnianych osób prawdopodobnie miało miejsce „w lokalu w resteuracji u Kowala Józefa w Zbydniowie” ${ }^{94}$. Julian Chruściel, stając się jednym z członków Oddziału, brał czynny udział w rozbrojeniu posterunków MO oraz w akcjach ekspropriacyjnych na terenie powiatu tarnobrzeskiego. Gajda pozyskiwał od niego informacje dotyczące planowanych zasadzek na żołnierzy podziemia niepodległościowego urządzanych przez funkcjonariuszy UB ${ }^{95}$. Chruściel zaopatrywał także oddział „Tarzana” $\mathrm{w}$ amunicję będącą własnością milicjantów posterunku MO w Zbydniowie ${ }^{96}$.

6 maja 1946 r. Julian Chruściel został zatrzymany przez funkcjonariuszy MO z Sekcji Śledczej przy Powiatowej Komendzie MO w Tarnobrzegu pod zarzutem współpracy z „bandą terrorystyczną «Tarzana» na terenie powiatu tarnobrzeskiego" ${ }^{197}$. Z braku dowodów dochodzenie umorzono ${ }^{98}$. W wyniku ogłoszonej amnestii z dnia 22 lutego 1947 r. ${ }^{99}$ Chruściel przyznał się do działalności w strukturach NZW ${ }^{100}$, do którego należał oddział Tadeusza Gajdy ${ }^{101}$.

We wrześniu 1945 r. został zastrzelony dowódca jednej z placówek oddziału „Tarzana” - Teodor Bernas ps. „Dorek”102. W odwecie za jego śmierć, Tadeusz

92 AIPN Rz, 008o/768, Karta ewidencyjna, 17 września 1945, k. 3.

93 AIPN Rz, 042/668, Oświadczenie, 24 marca 1947, k. 6.

94 AIPN Rz, 042/668, Protokół przesłuchania podejrzanego, 3 lutego 1946, k. 2.

95 AIPN Rz, 042/668, Oświadczenie, 24 marca 1947, k. 6-8.

96 AIPN Rz, 042/668, Wniosek o zaniechanie rozprawy i złożenie sprawy w archiwum Wydz. X., 20 lutego 1956, k. 12.

97 AIPN Rz, oo8o/768, Sprawozdanie nr 555/4050/46, 6 sierpnia 1946, k. 8.

98 Tamże.

99 Dz. U., 1947, nr 20, poz. 78.

100 AIPN Rz, 042/668, Oświadczenie, 24 marca 1947, k. 6-8.

101 Z powodu braku źródeł archiwalnych nie jest możliwe ustalenie, jak potoczyły się losy milicjanta.

102 Teodor Bernas „Dorek” (1917-1945) - członek Oddziału Leśnego nr 2 „Tarzana”, dowódca placówki terenowej w Grębowie, zastrzelony przez patrol posterunku MO w Gorzycach; AIPN Rz, 042/1873, Wyciąg z protokołu przesłuchania Rędzia Władysława s. Józefa, 9 lutego 1946, k. 3. 
Gajda otrzymał od komendanta PAS - Ludwika Więcława "Kłosa”- rozkaz rozbrojenia posterunku MO w Gorzycach ${ }^{103} \mathrm{w}$ ówczesnym powiecie tarnobrzeskim. Głównym celem ataku było ujęcie trzech milicjantów odpowiedzialnych za śmierć Bernasa ${ }^{104} .23$ września 1945 r. oddział „Tarzana” przeprowadził udaną akcję na Posterunek Mo w Gorzycach ${ }^{105}$. Pomyślne wykonanie rozkazu było skutkiem tajnej współpracy Gajdy z kolejnym funkcjonariuszem MO - Józefem Lipką, który w dniu rozbrojenia posterunku pełnił wartę. Milicjant Lipka „bez przeszkód wpuścił osobników do wnętrza, możliwie, że im dobrowolnie otworzył drzwi, [...] bowiem drzwi nie były uszkodzone, a [brama] żelazna nie naruszona"106. Po opanowaniu posterunku w Gorzycach, funkcjonariusz Lipka zdezerterował z szeregów Mo, jednocześnie wstępując do Oddziału Leśnego „Tarzana”107. Za byłym milicjantem rozesłano po całym kraju listy gończe, które dopiero w $1954 \mathrm{r}$. anulowano z powodu braku informacji dotyczących miejsca pobytu ściganego Józefa Lipki ${ }^{108}$.

Przedstawione drogi życiowe informatorów „Tarzana”, w kontekście ich współpracy z polskim podziemiem antykomunistycznym na obszarze byłego powiatu tarnobrzeskiego, są wybranymi przykładami biografii osób stojących na pograniczu dwóch przeciwstawnych sobie struktur. Z oddziałem „Tarzana” współpracowali także milicjanci: Jerzy Głogowski, Włodzimierz Uchański, Wilhelm Ołpiński oraz sam kierownik PUBP w Tarnobrzegu - Ludwik Moskwa. Z pewnością byli i tacy, o których prawda historyczna nigdy nie zostanie poznana z uwagi na brak jakichkolwiek źródeł. Jedno jest pewne - ich poświęcenie oraz ofiara zasługują na pamięć i cześć. Upowszechnianie biografii tych osób ma szczególny wymiar transmisji wychowawczej dokonującej się na podstawie przykładów postaw pełnych poświęcenia i oddania w walce na rzecz wolności i demokracji. Bohaterami byli ludzie młodzi i zwyczajni - maszynistka

103 B. Szwedo, „Tarzan” i jego żołnierze, s. 21.

104 D. Garbacz, Tadeusz Gajda „Tarzan”, s. 15.

105 AIPN Rz, 0172/4/J, Karta na czyn przestępczy dokonany przez bandę „Narodowa Organizacja Wojskowa” pod d-twem Gajda Tadeusza ps. „Tarzan, 14 października 1980.

106 AIPN Rz, 716/46, Napad i rozbrojenie Posterunku M. O. w Gorzycach, 24 września 1945, k. 36 .

107 AIPN Rz, 108/5445, Pismo skierowane do Wojskowej Prokuratury Rejonowej w Rzeszowie, 12 maja 1954, k. 1.

108 AIPN Rz, 108/5445, Postanowienie o odwołaniu listów gończych, 17 maja 1954, k. 2. 
Strutyńska i milicjanci: Lipka oraz Chruściel. Pamięć o tych osobach, stojących na pograniczu dwóch odmiennych rzeczywistości, dokonujących wyborów zgodnych z własnym sumieniem i przekonaniem, nadaje im rangę biografii bohaterów.

Streszczenie: Oddział Leśny Tadeusza Gajdy „Tarzana” był jedynym zgrupowaniem NZW w północnej części wideł Wisły i Sanu walczącym z procesem umacniania się nowej władzy w Polsce od 1944 r. Działalność „Tarzana” i jego żołnierzy na wyżej wspomnianym terenie trwała ponad rok. Fakt ten był zasługą dobrego dowodzenia oraz posiadania siatki informatorów, którzy działając w służbie władzy komunistycznej, pracowali w strukturach Urzędu Bezpieczeństwa Publicznego (UBP) i Milicji Obywatelskiej (MO). Osoby te, znalazły się na granicy utrwalającej się władzy komunistycznej i walczącego z nią polskiego podziemia niepodległościowego. Informatorzy „Tarzana” współpracując z oddziałem dokonali świadomego wyboru poświęcenia wartości najważniejszej - życia.

Słowa kluczowe: polskie podziemie niepodległościowe, struktury komunistyczne, biografie, aparat bezpieczeństwa, Milicja Obywatelska, współpraca

\section{Bibliografia}

\section{Źródła}

Dz. U., 1945, nr 27, poz. 168.

Dz. U., 1947, nr 20, poz. 78.

Archiwum Instytutu Pamięci Narodowej, Oddział w Rzeszowie [dalej: AIPN Rz], 05/19, 042/668, 043/12, 0172/4/J, 107/109, 122/269, 180/124/J, 716/46, 052/355, 0080/768, 0172/4/J, 108/5445.

Zbiory prywatne p. Haliny Bogaczyk, Związek Więźniów Politycznych Okresu Stalinowskiego Zarząd Główny w Warszawie, 17 lipca 1992, [pismo].

Wywiad z Henrykiem Strutyńskim, 2 maja 2016.

\section{Opracowania}

Bereza T., Chmielowiec P., Kaczmarski K., Polskie podziemie niepodległościowe $w$ województwie rzeszowskim 1944-1956, w: Atlas polskiego podziemia niepodległościowego1944-1956, red. R. Wnuk, S. Poleszak, A. Jaczyńska, M. Śladecka, WarszawaLublin 2007.

Borowiec J., Aparat bezpieczeństwa a wojskowy wymiar sprawiedliwości. Rzeszowszczyzna 1944-1954, Warszawa 2004. 
Borowiec J., Polityka karna wobec przestępstw i wykroczeń funkcjonariuszy Urzędu Bezpieczeństwa w województwie rzeszowskim (1944-19156), Rzeszów 2014.

Byszuk D., Komenda Powiatowa Milicji Obywatelskiej w Tarnobrzegu w latach 19441954, w: Powiat tarnobrzeski w latach 1944-1956, red. Z. Nawrocki, T. Zych, Tarnobrzeg 2005.

Dobosz S., Dzieje polityczne Tarnobrzega i powiatu tarnobrzeskiego w latach 1944-1975, w: Tarnobrzeg. Dzieje miasta 1939-1999, red. F. Kiryk, Mielec 2010.

Garbacz D., Tadeusz Gajda „Tarzan”, „Sztafeta”, 27 (2014) nr 9.

Historia Roja, czyli w ziemi lepiej słychać, [film], reż. J. Zalewski, Dr Watkins 2016.

Iwaneczko D., Ogniwo strachu. Urząd Bezpieczeństwa w Lubaczowie 1944-1956, Rzeszów 2012.

Iwaneczko D., Z. Nawrocki, Województwo rzeszowskie, w: Aparat bezpieczeństwa w Polsce. Kadra Kierownicza 1944-1956, red. K. Szwagrzyk, t. 1, Warszawa 2005.

Jakubowski Z., Milicja Obywatelska 1944-1948, Warszawa 1988.

Jubileusz 100-lecia Kościoła Św. Mikołaja Biskupa w Zaleszanach 1906-2006, red. J. Domin, M. Cygan, Zaleszany 2006.

Kaczmarski K., Krzysztofiński M., Podziemie antykomunistyczne na Rzeszowszczyźnie po 1944 r., „Nowe Państwo - Niezależna Gazeta Polska”, dodatek specjalny IPN, 8 (2010).

Korga L., Lata Polski Ludowej, w: Z rewolucyjnych walk na Rzeszowszczyźnie, red. Z. Trawińska, Rzeszów 1979.

Majer P., Milicja Obywatelska w systemie organów władzy PRL (zarys problematyki i źródła), Toruń 2003.

Muszyński W. J., Antykomunistyczne powstanie, w: Do końca wierni. Żołnierze wyklęci 1944-1963, red. D. P. Kucharski, R. Sierchuła, Poznań 2014.

Nowak Sz., Oddziały Wyklętych, Warszawa 2014.

Poleszak S., R. Wnuk, Zarys dziejów polskiego podziemia niepodległościowego 1944-1956, http://pamiec.pl/pa/edukacja/akcje-i-obchody/ogolnopolskie/1-marca-narodowydzien/historia/10063,dok.html?poz=2, dostęp: 07.04.2016.

Roszkowski W., Historia Polski 1914-2004, Warszawa 2004.

Socha S., Czerwona śmierć czyli narodziny PRL, Stalowa Wola 2000.

Szwagrzyk K., Aparat bezpieczeństwa w latach 1944-1956, w: Aparat bezpieczeństwa w Polsce. Kadra Kierownicza 1944-1956, red. K. Szwagrzyk, t. 1, Warszawa 2005.

Szwedo B., „Tarzan” i jego żołnierze, „Tarnobrzeskie Zeszyty Historyczne”, 13 (1996).

Żebrowski L., Żołnierze wyklęci. Antykomunistyczne podziemie zbrojne po 1944 roku, Warszawa 1999. 